\title{
INVESTIGASI DALAM PROSES PEMBELAJARAN MATEMATIKA
}

\author{
Oleh: A.Ika Prsasti Abrar \\ Pendidikan Matematika UIN Alauddin Makassar \\ E-mail: Asty_math03@yahoo.co.id
}

\begin{abstract}
Abstrak:
Di Inggris istilah investigasi (penyelidikan) mulai muncul di kancah pembicaraan para guru sejak diterbitkannya laporan Cockcroft pada tahun 1982 yang menyatakan bahwa pengajaran matematika harus melibatkan aktivitas-aktivitas berikut: Eksposisi atau pemaparan guru (exsposition); Diskusi di antara siswa sendiri, ataupun antara siswa dengan guru (discussion); Kerja praktek (practical work); Pemantapan dan latihan pengerjaan soal (consolidation); Pemecahan masalah (problem solving); Penyelidikan (investigation). pemecahan masalah merupakan kegiatan memusat (convergent activity) dimana para siswa harus belajar mencari penyelesaian yang sudah jelas arahnya, sedangkan investigasi adalah suatu kegiatan menyebar (divergent activity) dimana para siswa lebih diberikan kesempatan untuk memikirkan, mengembangkan, dan menyelidiki halhal yang menarik yang mengusik rasa keingintahuan mereka.
\end{abstract}

Kata Kunci: Investigasi, Pembelajaran, Matematika

\section{PENGANTAR}

Beberapa cara untuk mengaktifkan siswa agar berfikir dan bernalar adalah dengan memberikan soal yang mengarah pada jawaban konvergen, divergen, dan penyelidikan (investigasi). Istilah investigasi sendiri lebih banyak muncul di Inggris Raya (United Kingdom) dan Australia bersamaan terbitnya laporan Cockroft. Tulisan singkat ini akan membahas tentang kegiatan yang disebut penyelidikan dan akan dibagi dalam beberapa bagian dan akan dimulai dengan membahas pengertian penyelidikan, terutama apa bedanya dengan pemecahan masalah, diikuti dengan contoh penyelidikan tentang lompat katak, dan akan diakhiri dengan pembahasan mengenai mengapa guru harus memfasilitasi siswanya untuk melakukan kegiatan penyelidikan ini. 


\section{PEMBAHASAN}

\section{A. Pengertian Penyelidikan}

Menurut Evans (1987), di Inggris istilah investigasi (penyelidikan) mulai muncul di kancah pembicaraan para guru sejak diterbitkannya laporan Cockcroft pada tahun 1982 yang menyatakan bahwa pengajaran matematika harus melibatkan aktivitas-aktivitas berikut:

1) Eksposisi atau pemaparan guru (exsposition)

2) Diskusi di antara siswa sendiri, ataupun antara siswa dengan guru (discussion)

3) Kerja praktek (practical work)

4) Pemantapan dan latihan pengerjaan soal (consolidation)

5) Pemecahan masalah (problem solving)

6) Penyelidikan (investigation)

Masih menurut Evans (1987), jika di Inggris pemecahan masalah dibedakan dari penyelidikan, maka di AS kedua istilah tersebut tidak dibedakan, dalam arti penyelidikan dimasukkan ke lingkup kegiatan pemecahan masalah yang sejak tahun 1985 sudah menjadi agenda aksi para guru matematika untuk dilaksanakan berdasarkan rekomendasi NCTM, suatu organisasi para guru matematika di AS yang sangat disegani di seluruh dunia.

Lalu, apa beda antara pemecahan masalah dengan penyelidikan? Evan (1987) menyatakan bahwa pemecahan masalah merupakan kegiatan memusat (convergent activity) dimana para siswa harus belajar mencari penyelesaian yang sudah jelas arahnya, sedangkan investigasi adalah suatu kegiatan menyebar (divergent activity) dimana para siswa lebih diberikan kesempatan untuk memikirkan, mengembangkan, dan menyelidiki hal-hal yang menarik yang mengusik rasa keingintahuan mereka. Pada kegiatan ini investigasi, dapat saja terjadi, si A tertarik untuk menyelidiki $x$ sedangkan si B berminat untuk menyelidiki bagian yang lain yaitu $y$. di samping itu, dapat saja si A hanya tertarik untuk menyelidiki bagian-bagian permukaannya saja, sedangkan si B dengan kemampuan berpikir yang sangat prima menyelidiki hal-hal tersebut secara mendalam dan terinci. Itulah sebabnya penyelidikan ini disebut juga suatu kegiatan terbuka dan tidak terbatas, karena kegiatan ini sangat tergantung pada ketertarikan dan perbedaan kemampuan berpikir setiap siswa yang tentunya sangat berbeda. 
59 | al-Khwarizmi, Volume III, Edisi 2, Oktober 2015, Hal. 57 - 62

B. Contoh Penyelidikan

Contoh berikut akan menunjukkan perbedaan antara penyelidikan (investigation) dengan pemecahan masalah (problem solving). Penyelidikan ini disebut 'lompat katak', diama tiga batu putih dan tiga batu hitam yang mewakili dua jenis katak diletakkan di medan permainan seperti ini.

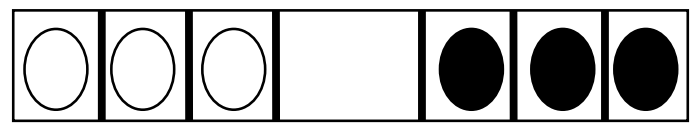

Gambar 1.

Kedua jenis batu itu harus dipertukarkan tempatnya dengan aturan:

1) Batu putih hanya dapat digerakkan ke kanan dan batu hitam hanya dapat digerakkan ke kiri;

2) Batu dapat digeser satu tempat ke tempat kosong di sebelahnya atau melompati satu batu yang erwarna lain ke satu tempat kosong berikutnya.

Pada kegiatan pemecahan masalah, perintahnya dapat saja berupa pertanyaan seperti berikut:

1) Bagaimana cara menukar tempat 3 batu putih dan 3 batu hitam itu?

2) Jika ada $n$ batu putih dan $n$ batu hitam, berapa langkah yang anda butuhkan?

Sekali lagi, pada pemecahan masalah, hal-hal yang harus dilakukan sudah tertentu dan sudah terarah. Itulah sebabnya, Evans menyatakan bahwa pemecahan masalah merupakan kegiatan memusat. Namun, pada penyelidikan, perintahnya hanya 'selidiki', artinya siswa sendirilah yang harus memunculkan pertanyaan dan menentukan satu atau lebih aspek yang akan diselidiki. Itulah sebabnya Bastow, dkk (1986) menyatakan, "Investigation is not just getting the right answers but asking the right questions". Suatu proses penyelidikan dapat saja dimulai dari hal-hal yang sangat sederhana dan mudah. Alih-alih menggunakan 3 buah batu putih dan hitam, para siswa dapat saja menggunakan 1 batu putih dan hitam seperti tampak pada gambar di bawah ini. 


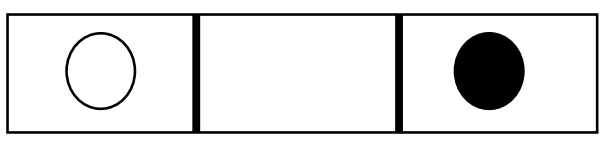

Gambar 2.

Langkah pertama adalah menggeser batu putih yang ada di petak ke petak 2, diikuti dengan batu hitam melompati batu putih ke petak 1 dan diakhiri dengan menggeser yang sudah berada di petak 2 ke petak 3. Dengan bimbingan guru, data yang dapat diharapkan akan didapat siswa dari penyelidikan awal tadi adalah salah satu atau seluruh data berikut.

1) Dibutuhkan 3 langkah untuk memutar tempat kedua jenis batu itu;

2) Ketiga langkah tersebut adalah menggeser - melompat menggeser yang dapat dinotasikan dengan GLG ( $\mathrm{G}=$ geser, $\mathrm{L}$ = lompat);

3) Urutan warna batu yang digerakkan adalah putih-hitam-putih dengan notasi PHP.

Berdasarkan data di atas, seorang siswa dapat aja menduga bahwa untuk 2 batu putih dan hitam dibutuhkan 5 langkah yang terdiri atas GL-GLG, dengan urutan-urutan warna batu yang digerakkan adalah PHPHP ( $\mathrm{P}=$ putih, $\mathrm{H}=$ hitam). Setelah diuji, kedua dugaan itu salah semua karena dibutuhkan 8 langkah dan bukan 5 langkah untuk saling menukar tempat kedua jenis batu itu, yang terdiri atas langkah-langkah GLGLL-GLG dengan urutanurutan warna batu yang digerakkan adalah PHHPPHHP. Perhatikan pola menarik pada GLGLLGLG ataupun PHHPPHHP. Proses penyelidikan di atas dapat dilanjutkan dengan $3,4,5, \ldots$ batu putih dan batu hitam untuk menemukan pola, menggeneralisasi, membuktikan, dan mengkomunikasikan proses dan hasil penyelidikan itu.

\section{Mengapa harus penyelidikan?}

Pepatah Cina yang digunakan Kissane (1988) untuk menunjukkan pentingnya kegiatan penyelidikan ini dipelajari para siswa ketika duduk di bangku sekolah adalah " A person given a fish is fed for a day". A person taught to fish is fed for life". Jelaslah bahwa dengan kegiatn penyelidikan ini, para siswa dilatih untuk tidak hanya menerima sesuatu yang sudah jadi layaknya diberi seekor ikan yang dapat dan tinggal dimakan selama sehari saja, namun mereka dilatih seperti layaknya belajar cara 
61 | al-Khwarizmi, Volume III, Edisi 2, Oktober 2015, Hal. 57 - 62

menangkap ikan tersebut sehingga ia bisa makan ikan selama hidupnya.

Untuk itu, selama proses pembelajaran di kelas, para siswa harus mempelajari cara-cara menemukan teori sederhana selama duduk di bangku sekolah yang diharapkan akan berguna kelak di kemudian hari. Di era globalisasi dan teknologi maju seperti sekarang, para pemecah masalah tangguh dan penemu besar akan semakin dibutuhkan. Denganbelajar dan berlatih menyelidiki sejak dini diharapkan akan uncul penemu-penemu besar dari bumi ini.

\section{PENUTUP}

Penyelidikan sangatlah penting untuk dipelajari siswa, sehingga kurikulum perlu menuntut pelaksanaan kegiatan itu selama proses pembelajaran. Namun harus diakui bahwa penyelidikan belum dapat terlaksana secara merata. Mungkin saja, tidak ada guru matematika yang melaksanakannya. Karenanya, ke depan ketika otonomi daerah sudah diberlakukan, sudah saatnya warga masyarakat menyadari akan pentingnya menyiapkan dan memperhitungkan segala sesuatunya secara bertahap, matang, dan terencana sebelum memasukkan suatu inovasi ataupun terobosan penting ke dalam dokumen resmi. Untuk itu, perlu dilakukan uji coba terlebih dahulu, menyiapkan pedoman untuk guru dan bahan ajar untuk siswa, dan yang tidak kalah pentingnya adalah mengUN-kan kegiatan baru tersebut. Hanya dengan cara seperti itulah, inovasi dan terobosan baru untuk mempercepat pencerdasan kehidupan bangsa ini dapat terlaksana sesuai dengan idaman dan cita-cita kita semua. 
Representasi Matematika Al-Quran ...| 62

\section{DAFTAR PUSTAKA}

Bastow, B. Hughes, J. Kissane, B. \& Randall, R. (1984). 40. Investigational Works. Perth: MAWA. . (1986). Another 20 Investigational Work. Perth: MAWA.

Evans, J. (1987). Investigations, the state of the art. Mathematics in school. January, hal.27-30

Kissane, B.V. (1988). Mathematical investigation: Descriptions, Rationale, and Example. Mathematics Teacher 81 (7), pp 520-522.

Mottershead, L. (1985). Investigations in Mathematics. Great Britain: Basil Blackwell. 